Article

\title{
Applying the Theory of Consumption Values to Explain Drivers' Willingness to Pay for Biofuels
}

\author{
Suhaiza Zailani ${ }^{1}$, Mohammad Iranmanesh ${ }^{2}{ }^{-}$, Sunghyup Sean Hyun ${ }^{3, *}$ and Mohd Helmi Ali ${ }^{4}$ \\ 1 Faculty of Business and Accountancy, University of Malaya, Kuala Lumpur 50603, Malaysia; \\ shmz@um.edu.my \\ 2 Graduate School of Business, Universiti Sains Malaysia, Penang 11800, Malaysia; iranmanesh@usm.my \\ 3 School of Tourism, Hanyang University, Seoul 133-791, Korea \\ 4 Faculty of Economics and Management, Universiti Kebangsaan Malaysia, Selangor 43600, Malaysia; \\ mohdhelmiali@ukm.edu.my \\ * Correspondence: sshyun@hanyang.ac.kr
}

Received: 9 December 2018; Accepted: 24 January 2019; Published: 28 January 2019

\begin{abstract}
The transportation sector has dominated global fuel consumption and as a result, greenhouse gas emissions have risen at an alarming rate. As a consequence, many countries have adopted policies and strategies to diversify their fuel sources in the transportation sector. Biofuel is one of the potential substitution fuels that has attracted the attention of both researchers and policy makers. Public acceptance of biofuels is one of the major challenges for the implementation of biofuel blends in transportation. To determine the influence of different values that affect drivers' willingness to pay for biofuels, the theory of consumption values is applied in the present research. The data were gathered by distributing questionnaires to 343 Malaysian people with driving licences and access to cars. The data were analysed using the partial least squares technique. The results of the analysis revealed that functional values, specific condition, emotional values and novelty seeking were among the main factors that influence drivers' willingness to pay for biofuels. Social values were shown to not be a significant factor. The results of the study contribute to the literature by testing the relationship between consumption values and willingness to pay for biofuels. The information provided in the present research might be beneficial for policy makers in modifying tactics and strategies towards the successful promotion of the usage of biofuels in developing countries.
\end{abstract}

Keywords: biofuels; willingness to pay; consumption values; Malaysia

\section{Introduction}

The rapid increase in carbon emissions has been a major contributor to the greenhouse effect, which has raised alarms about global warming [1]. Transportation is responsible for most of the consumption of limited non-renewable energy and therefore, is among the major energy consumption industries that have a negative impact on the living environment. Moreover, being responsible for the production of almost $27 \%$ of the total carbon emissions, the transportation sector has become the second largest carbon contributor due to its high dependence on fossil fuels [2]. Indeed, transportation is one of the industries that produces the fastest growing amount of emissions [3]. In this regard, the consumption and usage of alternative fuels, such as biofuels, solar power and fuel cells, have been proposed as a strategy to tackle the high consumption of fossil fuel in transportation.

Biofuels are among the potential substitution fuels that have attracted the attention of both researchers and policy makers. As mentioned by Savvanidou et al. [4], the term 'biofuel' is generally derived from the domain of biotechnology. All forms of processed fuels that are derived from biomass are included and covered by this term [5]. Biofuel is regarded as the most promising alternative for 
immediately confronting the problem of carbon emissions and energy consumption [6-8]. The reason for such a promising view of biofuel is the possibility of the direct usage of the current blended biofuel in conventional engines with no major modifications [9]. Moreover, Tong et al. [10] suggested the possibility of supplying blended biofuel using existing petrol facilities. Another advantage is the existence of numerous types of feedstock through which the continuous supply of feedstock for biofuel production can be guaranteed [11]. Regarding replacement fuels in transportation, Kumari and Singh [12] referred to bioethanol and biodiesel as the two most favourable biofuel products. Currently, these two commercialized products are produced mainly from vegetable oil, such as soybean and sugarcane for the production of bioethanol and palm oil and rapeseed for the production of biodiesel. The first generation of biofuel is considered to be produced from edible oil.

Biofuels accounted for only $4 \%$ of the world's total road fuel consumption in 2016 and their share has remained very low [13]. However, this is despite the fact that the importance of biofuel implementation is widely acknowledged in the road transport sector. This is mainly due to the costly process of the production of biofuels in comparison with the conventional fuels consumed in transportation [6]. As mentioned by Moser [14], there is no concurrence among consumers regarding their willingness to select environmentally friendly but more expensive products. However, less research has aimed to explore drivers' willingness to choose biofuels as a higher priced but environmentally friendly product, especially in Malaysia. The previous studies have focused mainly on the supply perspectives relating to product capacity and feedstock, biofuel policies and the relevant technologies. Indeed, there seems to be a lack of research into consumer perspectives regarding the consumption of biofuels [15], with only one study by Jansson et al. [15] examining the drivers of alternative fuel vehicle adoption. More specifically, it is extremely rare to find a comprehensive study that both theoretically and empirically explores and describes the ways in which drivers' willingness to pay for biofuels is shaped. Therefore, the theory of consumption values [16], which is a strong predictive theory for describing environmental human behaviours, forms the theoretical framework of the present research. Generally, the application of theory-driven research leads to a better understanding of those behavioural factors that influence a particular behaviour. The present paper makes a significant contribution to the field in two ways. First, it encompasses the development of new empirical evidence on biofuels, which has received attention as a prospective future scenario. Secondly, to the best of our knowledge, this research is the first empirical study that explores the ways in which consumers' willingness to pay for biofuels is influenced by specific values.

The outline of the research is as follows. The related literature on biofuels will be presented in Section 2. Next, Section 3 will be dedicated to the development of the model conceptualization and the hypothesis of the study. The research methodology will be described in Section 4 . The empirical study to validate the theoretical model of the research will be presented in Section 5. Subsequently, the discussion and contribution of the research will be provided. Finally, the final section will provide the limitations of this study.

\section{Biofuels}

The term 'biofuel' encompasses all the liquid and gaseous fuels in transportation that are predominantly derived from biomass [5]. Biodiesel, biomethanol, bioethanol and bio-oil are all examples of biofuels. Biodiesel and bioethanol have been presently regarded as the two most promising biofuels in transportation as the replacements for conventional fossil fuels. Using the appropriate catalysts, biodiesel is typically synthesised through the transesterification of vegetable oils. The application of biodiesel involves substituting mineral diesel in compression-ignition (CI) engines. This has the advantage of providing approximately similar properties without the need for any major modifications of the engines. Conversely, bioethanol is beneficial in replacing gasoline in petrol engines. Notably, it does not require any modifications in the engine as all vehicles are able to drive using a blend with $5 \%$ biofuel. Besides, the majority of car companies accept and cover engine warranties at blends with even higher percentages. In addition, compared to conventional diesel, a higher cetane 
number will be provided for a lower content of BTU in biodiesel when blended at $5 \%$. Accordingly, comparable efficiency, torque, horsepower and haulage rates can be attained. The performance of the engine is also positively affected by the use of bioethanol blends. This means that the engine's combustion will be improved through the addition of bioethanol to common petrol, which acts as an octane enhancer.

Nevertheless, biofuel production normally requires additional pretreatment stages, which will increase the overall production cost. As discussed by Salmela and Varho [17], consumers have not adopted green energy mainly due to higher market prices, which is the result of higher generation costs. According to public opinion surveys, $30 \%$ of consumers would agree to paying a price premium for green energy [18-20]. The mass public willingness to use biofuel blends is very important in the promotion of biofuel usage. This is because the public constitute the major consumers of conventional fossil fuels and their unwillingness to change to biofuels can result in catastrophic failure of the strategy, as shown in Canada and New Zealand regarding the usage of natural gas [21]. Hence, the present study explores the factors and elements that affect drivers' willingness to pay for biofuels.

\section{Model Conceptualization and Hypothesis Development}

Within the context of environmental behaviour and in terms of the values, consumers' willingness to pay for biofuels has not been investigated in the previous literature. Schwarts and Bilsky [22] defined values as "concepts or beliefs about desirable end states or behaviours that transcend specific situations, guide selection or evaluation of behaviour and events and are ordered by relative importance" p. 551 . As maintained by Holbrook [23], the implied criteria that shape consumers' preferences and evaluative judgments are influenced by their values. Long and Schiffman [24] also referred to values as factors that direct judgments, attitudes and actions in addition to influencing the assessment of particular objects and situations.

There has been extensive support regarding the influence of values on making decisions and behaviours in favour of the environment [25]. However, it can be argued that compared to the one-dimensional approach, studies have accentuated the multidimensional conceptualization of consumer values as a more significant element in predicting consumer decisions [26]. Sheth et al. [16] developed and set forth a theory of consumption values. According to this theory, behaviour is determined through five values. These values are categorized as the functional, social, emotional, conditional and epistemic values. Moreover, a green consumer's behaviour is shown to be influenced by Sheth et al.'s [16] theory $[27,28]$. Accordingly, the conceptualization of consumption values is supported in the present research.

Figure 1 shows the framework that is proposed for the investigation of the influence of consumption values on the willingness of consumers to pay for biofuels. The next sub-sections will provide the subsequent developed hypotheses. 


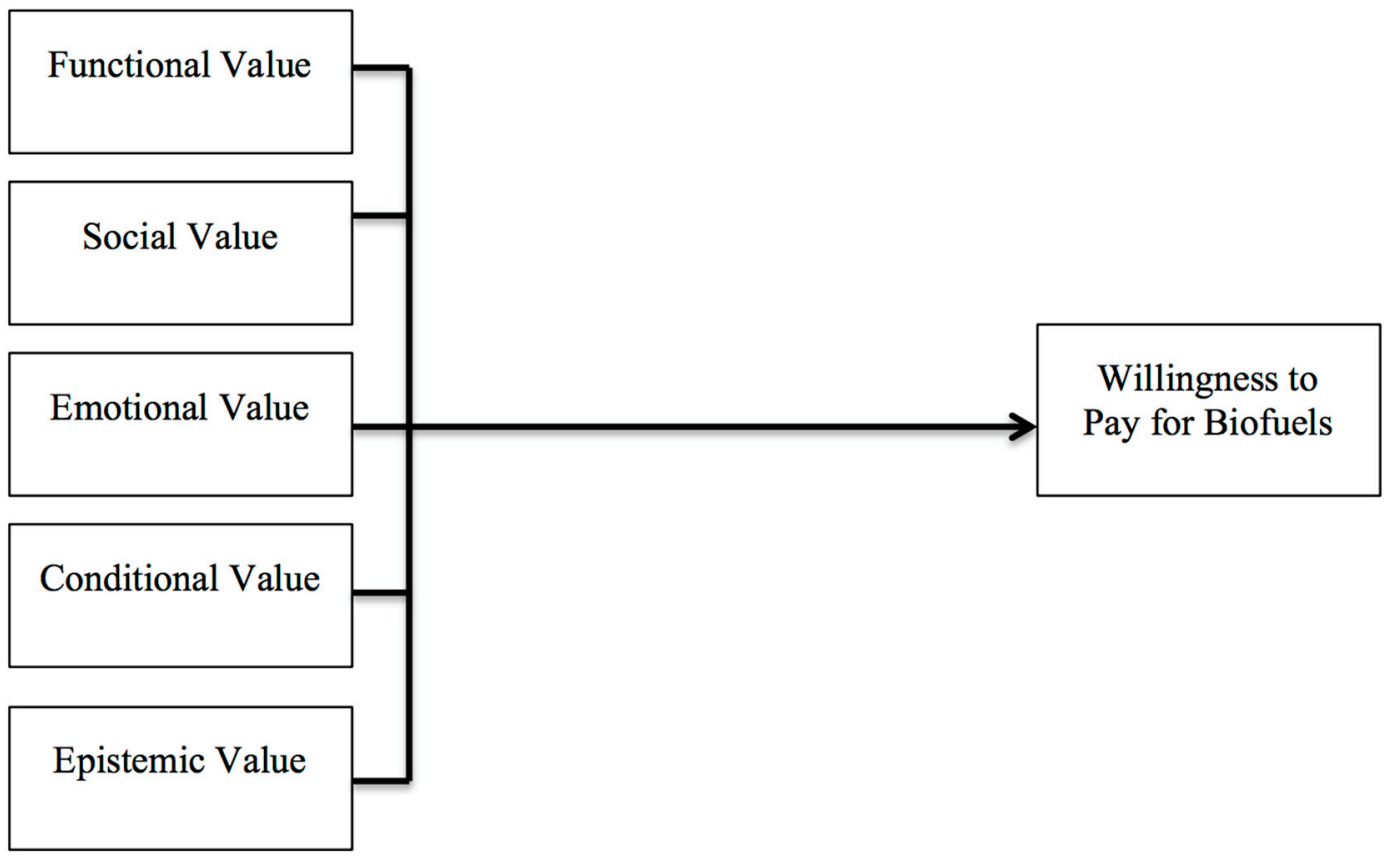

Figure 1. Proposed research framework.

\subsection{Functional Value}

Consumer choice is predominantly determined by the functional value. This function refers to "the perceived utility of a product or service to attain utilitarian or physical performances that results from attributes, such as durability, reliability and price" [16]. There are consumers for whom the issue of environmental degradation is so important that they are willing to spend more on green products [29]. Moreover, Bei and Simpson [30] reported that consumers also consider the price and quality of recycled products. Regarding green products, the primary driver in regulating consumers' choice behaviour is functional value [31-33]. Nevertheless, criteria other than the price would be selected by consumers in the case of high-priced products. According to Van et al. [34], although environmentally compatible packaging was not favoured in terms of price and taste, eco-friendly behaviour was exhibited by beverage consumers in Germany. Tsay [35] also determined that the Taiwanese consumers who belong to the higher income groups are more willing to pay higher premiums as they tend to envisage a superior quality for the green products. The extreme sensitivity of consumers towards the price of green products dose not reveal much responsibility to the environment [36]. Ultimately, the number of consumers who are willing to take substantive steps to counter environmental degradation and who are accordingly willing to pay premium prices for green products has increased in the more developed countries [37-40]. Hence, the following hypothesis can be developed based on these arguments.

Hypothesis 1. Functional value has a positive effect on drivers' willingness to pay for biofuels.

\subsection{Social Value}

According to Sheth et al. [16], the apparent utility that results from the service's or product's association with one or more social groups, such as socioeconomic, demographic or cultural groups, is referred to as the social value. Previous research has shown a positive relationship between social value and sustainable consumption behaviours [32,41]. This value contributes to the improvement of the self-image and approval [42] which affects a consumer's behaviour in relation to the environment [31]. As maintained by Oliver and Lee [43], studies on hybrid cars have found that the purchase intentions of consumers are positively related to their perceptions of the social value. The generalization of this discussion to the context of biofuels may suggest the buyers' enjoyment 
of social value from their biofuel usage. Consequently, the following hypothesis is generated in the present research:

Hypothesis 2. Social value has a positive effect on drivers' willingness to pay for biofuels.

\subsection{Emotional Value}

Emotional value refers to "the perceived utility that results from a product or service that provokes feelings or affective states" [16]. The study conducted by Bei and Simpson [30] indicated that $89.1 \%$ of the respondents believed that their purchase of recycled products would contribute to the preservation of the environment. Consumers' behaviour with regard to the environment is manipulated by the emotional value $[29,44]$. Although the explanatory power of decision-making models can be greatly improved through the incorporation of emotion into them [45-48], which is traditionally considered as a cognitive process, the function of emotion in decision making has remained less explored thus far [47]. In this regard, the following hypothesis is generated in this study:

Hypothesis 3. Emotional value has a positive effect on drivers' willingness to pay for biofuels.

\subsection{Conditional Value}

Conditional value is defined as "the perceived utility acquired by an alternative as the result of the specific situation or set of circumstances facing the choice maker" [16]. Such a condition is considered by Belk [49] as a situation in which, rather than relying on personal knowledge (intra-individual) and stimulus (choice of alternative) attributes, all of the included elements are related to particular times and places. In turn, this significantly and systematically shapes the current behaviour. When personal situations change, consumer purchase behaviour may be affected [50]. According to Biswas and Roy [32], conditional value plays a significant role in shaping sustainable consumption behaviour. Since consumer behaviour with regard to the environment is influenced by the conditional value, the following hypothesis is formulated in this research:

Hypothesis 4. Conditional value has a positive effect on drivers' willingness to pay for biofuels.

\subsection{Epistemic Value}

Epistemic value is defined as "the perceived utility acquired from an alternative's capacity to arouse curiosity, provide novelty and/or satisfy a desire for knowledge" [16]. According to Laroche et al. [38], in consumer research, all stages of the decision-making process are recognized to be influenced by a characteristic, which is referred to as knowledge. When encountering a new product, in deciding whether to opt for it or not, consumers evaluate the new product by comparing the newly introduced product with the already known ones [51]. For a newly introduced product to be adopted, there must be an equivalent elaboration between the perceived situational characteristics of the buyer and the characteristics of the product.

Novelty seeking serves as a means of self-preservation and the individual may find it useful to create a database of potentially useful knowledge [52]. Consumers may seek to attain information that seems to be "not useful" at the time but might assume great importance in the future. Novelty seeking can be referred to as a means to improve consumers' skills in problem solving. According to Ginsberg and Bloom [53], an attitude behaviour gap may arise between the actual behaviour of the buyer and the buyer's environmental concern as a result of the lack of information about green products. Thus, increasing the availability of information may fill the gap. Lin and Huang [29], Rahnama and Rajabpour [41] and Suki [54] found a positive relationship between epistemic value and a consumer's environmental concerns and behaviours. Accordingly, the following hypothesis is formulated:

Hypothesis 5. Epistemic value has a positive effect on drivers' willingness to pay for biofuels. 


\section{Research Methodology}

\subsection{Measure of Constructs}

A survey instrument was utilized in the present study. The survey consisted of three sections: the respondents' profile, their consumption values and their willingness to pay for biofuels. The content validity was ensured by deriving the survey items from previously conducted studies. Consumption values were adapted from Sweeney and Soutar [42], Arvola et al. [55] and Dholakia [56]. The willingness to pay items were adapted from Khan and Kirman [57]. It is important to highlight that the price of biofuel in Malaysia is dependent on the price of palm oil and the percentage of blending. At the time of study conducted in Malaysia, fuel was blended with 7\% palm-biofuel (B7), resulting in a $10 \%$ higher cost. Thus, we measured the willingness of drivers to pay $10 \%$ more for biofuel. A five-point Likert scale ranging from "Strongly Disagree" (1) to "Strongly Agree" (5) was used for the measurement of the items.

\subsection{Data Collection and the Sample}

The population of this study consisted of all Malaysian people living in Kuala Lumpur, Penang, Johor and Sabah who have a driving licence and a car. According to Iranmanesh et al. [58], these four states are sufficiently representative of the entire Malaysian population. Data collection was carried out by giving a hard copy of the questionnaire to 450 respondents. As it was not possible to access a list of all elements of the population, the data were collected using a convenience sampling technique. The questionnaire was administered to respondents in restaurants and coffee shops as individuals with different characteristics are available in these locations. Furthermore, the potential respondents would have time to fill in the questionnaire in these places. Those respondents who did not have a driving license or a car were identified by using filtering questions and were excluded from the analysis since the present study attempts to shed light on drivers' willingness to pay for biofuels. This resulted in a total of 343 responses or a $76.2 \%$ usable response rate. The power of a sample of 343 was tested using $G^{*}$ Power version 3.1.9.2 [59] and the results show that the sample has enough power (99.99\%) to test the hypotheses.

\subsection{Analysis}

The research model was examined through the employment of the partial least squares (PLS) technique of structural equation modelling. In this regard, the SmartPLS Version 3.0 was used. PLS is a causal modelling path that aims to increase the explained variance of dependent latent constructs. The main reason for the selection of this technique was the study's exploratory nature [60]. This study is exploratory as it is one of the first attempts to explain the relationships between consumption values and willingness to pay for biofuels. Based on Hair et al.'s [61] suggestions, the two-step approach was applied for analysis of the data in this research. In the first step, the measurement model was analysed to determine the validity and reliability of the constructs [62-64]. In the second step, the proposed hypotheses were tested using the bootstrapping technique with 2000 replications.

\section{Results}

\subsection{Sample}

Out of 343 respondents, $52.5 \%$ of the respondents were female and $47.5 \%$ were male (Table 1 ). A total of 132 respondents (38.5\%) were 30 years old or less, followed by 119 respondents $(34.7 \%)$ who were in the $31-45$ age range and 92 respondents $(26.8 \%)$ who were aged 46 years and above. With regard to ethnicity, $47.5 \%$ of the respondents were Malay, $36.7 \%$ were Chinese and $15.8 \%$ were Indian. In terms of respondents' educational status, $36.4 \%$ had a bachelor's degree, $28.9 \%$ had a diploma, $17.8 \%$ had a master's degree, $11.4 \%$ were in school and 5.5\% had a PhD. 
Table 1. Respondents' Profile.

\begin{tabular}{cccc}
\hline \multirow{2}{*}{ Gender } & & Frequency & Percentage (\%) \\
& Male & 163 & 47.5 \\
Age & Female & 180 & 52.5 \\
& 30 years or less & 132 & 38.5 \\
\multirow{5}{*}{ Race } & 31-45 years & 119 & 34.7 \\
& 46 years and above & 92 & 26.8 \\
& Malay & 163 & 47.5 \\
Education & Chinese & 126 & 36.7 \\
& Indian & 54 & 15.8 \\
& School & 39 & 11.4 \\
& Diploma & 99 & 28.9 \\
& Bachelor Degree & 125 & 36.4 \\
& Master Degree & 61 & 17.8 \\
& PhD & 19 & 5.5 \\
\hline
\end{tabular}

\subsection{Measurement Model Results}

To test the validity and reliability of the constructs (Table 2), the factor loadings, average variance extracted (AVE) and composite reliability (CR) were assessed [65-67]. The internal reliability was evaluated using CR and as all the values were above 0.7 , the internal reliability of the constructs was acceptable [61]. The factor loadings of all items were also greater than 0.6 and as such, individual item reliability was established [68]. The AVE of all constructs was also above 0.5 , which indicates a satisfactory level of convergent validity [69].

The discriminant validity of constructs was assessed using Fornell and Larcker's (1981) criterion. According to Fornell and Larcker (1981), the square root of the AVE for each construct should be more than the values of the intercorrelations of that particular construct with the other constructs (Table 3). Our results confirms the discriminant validity of the current study constructs.

Table 2. Measurement Model Evaluation.

\begin{tabular}{|c|c|c|c|c|c|c|}
\hline & Items & $\begin{array}{l}\text { Factor } \\
\text { Loadings }\end{array}$ & CR & AVE & Mean & $\begin{array}{c}\text { Std. } \\
\text { Deviation }\end{array}$ \\
\hline \multirow{7}{*}{$\begin{array}{l}\text { Functional Value } \\
\text { (FV) }\end{array}$} & Biofuels have consistent quality. & 0.632 & 0.898 & 0.561 & 3.642 & 0.716 \\
\hline & Biofuels are well made. & 0.701 & & & 3.721 & 0.783 \\
\hline & $\begin{array}{l}\text { Biofuels have an acceptable standard of } \\
\text { quality. }\end{array}$ & 0.688 & & & 3.211 & 0.921 \\
\hline & Biofuels are reasonably priced. & 0.845 & & & 3.376 & 0.864 \\
\hline & Biofuels offer value for money. & 0.832 & & & 3.245 & 0.891 \\
\hline & Biofuels are good fuels for the price. & 0.774 & & & 3.278 & 0.863 \\
\hline & Biofuels would be economical. & 0.745 & & & 3.372 & 0.811 \\
\hline \multirow[t]{4}{*}{ Social Value (SV) } & $\begin{array}{l}\text { Using biofuels would help me to feel } \\
\text { acceptable. }\end{array}$ & 0.811 & 0.793 & 0.564 & 3.148 & 0.783 \\
\hline & $\begin{array}{l}\text { Using biofuels would improve the way that } \\
\text { I am perceived. }\end{array}$ & 0.778 & & & 3.021 & 0.859 \\
\hline & $\begin{array}{l}\text { Using biofuels would make a good } \\
\text { impression on other people. }\end{array}$ & 0.654 & & & 3.317 & 0.761 \\
\hline & $\begin{array}{l}\text { Using biofuels would give the car's owner } \\
\text { social approval. }\end{array}$ & 0.739 & & & 3.165 & 0.859 \\
\hline \multirow[t]{3}{*}{$\begin{array}{l}\text { Emotional Value } \\
\text { (EMV) }\end{array}$} & $\begin{array}{l}\text { Using biofuels instead of conventional fuels } \\
\text { would feel like making a good personal } \\
\text { contribution to something better. }\end{array}$ & 0.648 & 0.761 & 0.516 & 3.487 & 0.722 \\
\hline & $\begin{array}{l}\text { Using biofuels instead of conventional fuels } \\
\text { would like the morally right thing. }\end{array}$ & 0.712 & & & 3.671 & 0.781 \\
\hline & $\begin{array}{l}\text { Using biofuels instead of conventional fuels } \\
\text { would make me feel like a better person. }\end{array}$ & 0.788 & & & 3.284 & 0.873 \\
\hline
\end{tabular}


Table 2. Cont.

\begin{tabular}{|c|c|c|c|c|c|c|}
\hline & Items & $\begin{array}{l}\text { Factor } \\
\text { Loadings }\end{array}$ & CR & AVE & Mean & $\begin{array}{c}\text { Std. } \\
\text { Deviation }\end{array}$ \\
\hline \multirow[t]{3}{*}{$\begin{array}{l}\text { Conditional Value } \\
\text { (CV) }\end{array}$} & $\begin{array}{l}\text { I would use biofuels instead of conventional } \\
\text { fuels under worsening environmental } \\
\text { conditions. }\end{array}$ & 0.872 & 0.875 & 0.701 & 3.011 & 0.978 \\
\hline & $\begin{array}{l}\text { I would use biofuels instead of conventional } \\
\text { fuels if there were a subsidy for biofuels. }\end{array}$ & 0.845 & & & 3.561 & 0.689 \\
\hline & $\begin{array}{l}\text { I would use biofuels instead of conventional } \\
\text { fuels when biofuels are available. }\end{array}$ & 0.793 & & & 3.344 & 0.749 \\
\hline \multirow{3}{*}{$\begin{array}{l}\text { Epistemic Value } \\
\qquad(\mathrm{EPV})\end{array}$} & $\begin{array}{l}\text { Before using biofuels, I would obtain } \\
\text { substantial information about the different } \\
\text { types of fuels. }\end{array}$ & 0.768 & 0.768 & 0.525 & 2.784 & 0.855 \\
\hline & I am willing to seek out novel information. & 0.681 & & & 3.101 & 0.741 \\
\hline & I like to search for what is new and different. & 0.722 & & & 3.375 & 0.727 \\
\hline \multirow{2}{*}{$\begin{array}{l}\text { Willingness to Pay } \\
\text { for biofuels (WTP) }\end{array}$} & It is acceptable to pay $10 \%$ more for biofuels. & 0.873 & 0.840 & 0.725 & 3.116 & 0.715 \\
\hline & I am willing to pay $10 \%$ more for biofuels. & 0.829 & & & 3.061 & 0.801 \\
\hline
\end{tabular}

$\mathrm{CR}=$ Composite Reliability; AVE = Average Variance Extracted.

Table 3. Discriminant Validity Coefficients.

\begin{tabular}{ccccccc}
\hline & FV & SV & EMV & CV & EMP & WTP \\
\hline FV & $\mathbf{0 . 7 4 9}$ & & & & & \\
SV & 0.418 & $\mathbf{0 . 7 5 1}$ & & & & \\
EMV & 0.413 & 0.521 & $\mathbf{0 . 7 1 8}$ & & & \\
CV & 0.453 & 0.487 & 0.328 & $\mathbf{0 . 8 3 7}$ & & \\
EMP & 0.536 & 0.539 & 0.416 & 0.722 & $\mathbf{0 . 7 2 5}$ & \\
WTP & 0.654 & 0.497 & 0.503 & 0.612 & 0.632 & $\mathbf{0 . 8 5 1}$ \\
\hline \multicolumn{7}{c}{ Diagonals (in bold) represent square root of the AVE. }
\end{tabular}

\subsection{Structural Model Results}

After the validity and reliability of the constructs were confirmed, the structural model was tested. The five consumption values have the power to explain $60.4 \%$ of the variance in drivers' willingness to pay for biofuel. Aside from evaluating the magnitude of $R^{2}$, the predictive relevance of the model was assessed using Stone-Geisser $\mathrm{Q}^{2}$ (cross-validated redundancy). The $\mathrm{Q}^{2}$ value of willingness to pay for biofuel (0.355) was greater than zero, which indicates that the model has high predictive relevance [70].

To test the developed hypotheses, nonparametric bootstrapping with 2000 replications was applied [71]. With the exception of one path (Hypothesis 2), all the paths were significant (Table 4). Therefore, Hypothesis 1, Hypothesis 3, Hypothesis 4 and Hypothesis 5 were supported, whereas Hypothesis 2 was not supported. The strength of the effect of the determinants on the willingness to pay for biofuels was examined by the effect size $\left(\mathrm{f}^{2}\right)$ [61]. A notable detail was that the functional value has the highest effect on willingness to pay $\left(f^{2}=0.218\right)$, followed by conditional value $\left(f^{2}=0.077\right)$, emotional value $\left(f^{2}=0.058\right)$ and epistemic value $\left(f^{2}=0.023\right)$.

Table 4. Path coefficient and hypothesis testing.

\begin{tabular}{lccccc}
\hline & Relationship & $\begin{array}{c}\text { Path } \\
\text { Coefficient }\end{array}$ & $\begin{array}{c}\text { Standard } \\
\text { Deviation }\end{array}$ & Effect Size & Decision \\
\hline Hypothesis 1 & FV -> WTP & $0.362^{* * *}$ & 1.016 & 0.218 & Supported \\
Hypothesis 2 & SV -> WTP & 0.042 & 0.064 & 0.003 & Not Supported \\
Hypothesis 3 & EMV -> WTP & $0.185^{* *}$ & 0.071 & 0.058 & Supported \\
Hypothesis 4 & CV -> WTP & $0.257^{* * *}$ & 0.081 & 0.077 & Supported \\
Hypothesis 5 & EPV -> WTP & $0.153^{*}$ & 0.076 & 0.023 & Supported \\
\hline $\begin{array}{l}\text { t-values are computed through bootstrapping procedure with } 343 \text { cases and } 2000 \text { samples. }{ }^{*} p<0.05,{ }^{* *} p<0.01, \\
* * *\end{array}<0.001$ (one tail).
\end{tabular}




\section{Discussion and Implications}

The findings of the research indicate a positive effect of functional value on drivers' willingness to pay for biofuels. The result is consistent with the findings by Biswas and Roy [32] and Singh and Pandey [72], who found functional value to be a driver of sustainable consumption behaviour. This effect suggests that drivers' willingness is significantly influenced by the biofuels' price and quality. In other words, drivers are willing to pay for the biofuels provided that the price is reasonable and the engine performance is not negatively affected. Thus, governments are bound to compel the manufacturers of vehicles to guarantee the capability of their produced engines to use the blended biofuels. If this was fulfilled, the quality of biofuels would be ensured for drivers. Regarding the reasonable price of biofuels, it is recommended that governments offer subsidies and supportive policies.

This study also finds no relationship between social value and willingness to pay for biofuels. This result is not consistent with the findings of Biswas and Roy [32] and Rahnama and Rajabpour [41], who found a positive relationship between social value and sustainable consumption behaviour. This might be due to the insignificant value that some of the respondents attached to the use of biofuels and to gaining social approval or making a good impression. According to Laroche et al. [38], many people have strong ecological concerns and thus believe that the government and/or big business should be responsible for the preservation of the environment. An investigation of consumers' behaviour by Kalafatis et al. [73] reported that, rather than social pressure, consumers' personal beliefs have a more determining influence on their actions. They concluded that there is no evidence of the influence of social norms and peer behaviour on consumers' choice behaviour. In addition, another study by Lin and Huang [29] also revealed no significant influence of social factors on a sample of Taiwanese consumers' choice behaviour with regard to green products.

The findings also suggest that emotional value has a significant influence on drivers' willingness to pay for biofuels. The finding is in line with the findings of Wang et al. [33] and Sangroya and Nayak [44]. Those drivers who favoured biofuels over the conventional ones in order to preserve the environment stated that they experienced positive feelings by doing good for both their society and themselves and accordingly, showed more interest in paying higher prices for biofuels. As such, governments should make people aware of the advantage to the environment conferred by using biofuels. For instance, useful information that can be provided is the amount by which carbon emissions are reduced through the use of biofuels. This emotional value is assumed to gradually result in consumers' increasing consumption of biofuels, leading them to identify themselves as environmental defenders.

Another significantly influential consumption value that affects willingness to pay for biofuel is the conditional value. Biswas and Roy [32] also found a positive relationship between the conditional value and sustainable consumption behaviour. This suggests that the financial subsidies, availability of biofuels and the current state of global warming are the main motivations for drivers to pay for biofuels. Accordingly, governments must continuously emphasize the importance of changes in the climate and their effects on the destruction of the environment. Moreover, governments are required to take certain actions, such as providing financial subsidies to the related companies, making biofuels available in petrol stations and accordingly, creating more opportunities for boosting conditional value. In this regard, this would result in consumers having a greater awareness of the environmental concerns and the potential consequences, which would in itself lead to a higher likelihood of biofuel consumption.

Finally, a positive relationship between the epistemic value and drivers' willingness to pay for biofuels can be observed in the results of this research, which is consistent with the findings of Rahnama and Rajabpour [41] and Suki [54]. There was more interest shown towards paying for biofuels by those drivers who had a desire or curiosity for knowledge and novelty. Hence, petroleum companies aiming to increase consumer knowledge and awareness should take into account both the characteristics of biofuels and the role of the attractions of biofuels compared to conventional fuels during promotions. Therefore, epistemic value is concerned not only with the provision of knowledge of biofuels, but also with styles of presentation for them, all of which will have potentially positive effects on drivers' willingness to pay for biofuels. 
In terms of the theoretical contribution, this study is the first to empirically investigate the impact of consumption values on willingness to pay for biofuels. Moreover, the results support the high explanatory power of the theory of consumption values in describing drivers' willingness to pay. In addition, the study is significant since the past literature lacks studies examining drivers' willingness to pay for biofuels in the Malaysian context. Apart from its theoretical implications, this research also provides recommendations for policy makers and petroleum companies. Empirical findings on the relative effect of each type of value on willingness to pay for biofuels enable policy makers and managers to gain improved knowledge on the factors that may motivate drivers to pay $10 \%$ more for biofuels. In summary, in addition to certain aspects, such as desirable price and quality (functional value), the policy makers and petroleum companies have to provoke a positive feeling in drivers (emotional value), such as reminding them that they are contributing to the preservation of the environment; creating special circumstances that lead to the purchase of biofuels (conditional value); or presenting the information in a way that stimulates the desire for knowledge and novelty (epistemic value).

\section{Conclusions}

The transport sector has the most rapidly growing demand for fossil fuels and carbon emissions. To reduce carbon emissions, biofuels have been viewed for decades as an alternative and renewable energy source. In Asia, Malaysia is considered to be one of the advocates of biofuel implementation in the country's transportation system. Due to several difficulties encountered in this course, Malaysia is unfortunately far away from being successful in this respect. As one of the main obstacles in fulfilling the implementation of biofuel blends in the transportation sector of the country, drivers' reluctance to pay higher prices should be mentioned. Thus, in order to investigate the underlying factors in drivers' willingness to pay higher prices, we applied the theory of consumption values in the present research. With the exception of one value, which was namely the social value, all consumption values, including functional value, emotional value, conditional value and epistemic value, have a significant effect on willingness to pay for biofuels. This result indicates that the theory of consumption values is a powerful theory in explaining drivers' willingness to pay for biofuels.

Although the objectives of the study have been successfully addressed, future studies are needed to address the limitations. Firstly, the results indicate that functional value, emotional value, conditional value and epistemic value have a significant effect on the willingness to pay for biofuels. However, the factors that affect these values are unclear. A future study can investigate the antecedents of consumption values. Secondly, the data were collected from drivers in Malaysia and thus, the findings may not be applicable to drivers in other countries. Therefore, the results of this study need to be tested with car drivers in other countries. Finally, this study is cross-sectional in nature and willingness to pay for biofuel may not show the actual behaviour of drivers. Future research is needed to measure the actual behaviour of drivers in paying $10 \%$ more for biofuel.

Author Contributions: S.Z. proposed the research framework and contributed to data collection; M.I. and M.H.A. analyzed the data and wrote the article; S.S.H. contributed to writing and revising article.

Funding: The authors would like to acknowledge the financial support provided by University of Malaya under the research grant GC001F-14AET.

Conflicts of Interest: The authors declare no conflict of interest.

\section{References}

1. Shuai, C.; Shen, L.; Jiao, L.; Wu, Y.; Tan, Y. Identifying key impact factors on carbon emission: Evidences from panel and time-series data of 125 countries from 1990 to 2011. Appl. Energy 2017, 187, 310-325. [CrossRef]

2. International Energy Agency (IEA). Energy Technology Perspectives 2017; International Energy Agency: Paris, France, 2017. 
3. Timilsina, G.R.; Shrestha, A. Transport sector CO2 emissions growth in Asia: Underlying factors and policy options. Energy Policy 2009, 37, 4523-4539. [CrossRef]

4. Savvanidou, E.; Zervas, E.; Tsagarakis, K.P. Public acceptance of biofuels. Energy Policy 2010, 38, 3482-3488. [CrossRef]

5. Demirbas, A. Progress and recent trends in biofuels. Prog. Energy Combust. Sci. 2007, 33, 1-18. [CrossRef]

6. Lim, S.; Lee, K.T. Implementation of biofuels in Malaysian transportation sector towards sustainable development: A case study of international cooperation between Malaysia and Japan. Renew. Sustain. Energy Rev. 2012, 16, 1790-1800. [CrossRef]

7. Xu, K.; Lv, B.; Huo, Y.-X.; Li, C. Toward the lowest energy consumption and emission in biofuel production: Combination of ideal reactors and robust hosts. Curr. Opin. Biotechnol. 2018, 50, 19-24. [CrossRef] [PubMed]

8. Rassoulinejad-Mousavi, S.M.; Mao, Y.; Zhang, Y. Reducing greenhouse gas emissions in Sandia methane-air flame by using a biofuel. Renew. Energy 2018, 128, 313-323. [CrossRef]

9. Milazzo, M.F.; Spina, F.; Vinci, A.; Espro, C.; Bart, J.C.J. Brassica biodiesels: Past, present and future. Renew. Sustain. Energy Rev. 2013, 18, 350-389. [CrossRef]

10. Tong, K.; Gleeson, M.J.; Rong, G.; You, F. Optimal design of advanced drop-in hydrocarbon biofuel supply chain integrating with existing petroleum refineries under uncertainty. Biomass Bioenergy 2014, 60, 108-120. [CrossRef]

11. Herrmann, R.; Jumbe, C.; Bruentrup, M.; Osabuohien, E. Competition between biofuel feedstock and food production: Empirical evidence from sugarcane outgrower settings in Malawi. Biomass Bioenergy 2018, 114, 100-111. [CrossRef]

12. Kumari, D.; Singh, R. Pretreatment of lignocellulosic wastes for biofuel production: A critical review. Renew. Sustain. Energy Rev. 2018, 90, 877-891. [CrossRef]

13. Letcher, T.M. Why do we have global warming? In Managing Global Warming; Elsevier: New York, NY, USA, 2019; pp. 3-15.

14. Moser, A.K. Consumers' purchasing decisions regarding environmentally friendly products: An empirical analysis of German consumers. J. Retail. Consum. Serv. 2016, 31, 389-397. [CrossRef]

15. Jansson, J.; Nordlund, A.; Westin, K. Examining drivers of sustainable consumption: The influence of norms and opinion leadership on electric vehicle adoption in Sweden. J. Clean. Prod. 2017, 154, 176-187. [CrossRef]

16. Sheth, J.N.; Newman, B.I.; Gross, B.L. Why we buy what we buy: A theory of consumption values. J. Bus. Res. 1991, 22, 159-170. [CrossRef]

17. Salmela, S.; Varho, V. Consumers in the green electricity market in Finland. Energy Policy 2006, 34, 3669-3683. [CrossRef]

18. Eurobarometer. "Energy: Issues, Options and Technologies, Science and Society", A Report Produced by The European Opinion Research Group (EORG) for the Directorate- General for Research; Eurobarometer: Luxembourg, 2003.

19. Eurobarometer. "Attitudes Towards Energy", A Report Produced by The European Commission for the DirectorateGeneral for Research; Eurobarometer: Luxembourg, 2005.

20. Zarnikau, J. Consumer demand for 'green power'and energy efficiency. Energy Policy 2003, 31, 1661-1672. [CrossRef]

21. Flynn, P.C. Commercializing an alternate vehicle fuel: Lessons learned from natural gas for vehicles. Energy Policy 2002, 30, 613-619. [CrossRef]

22. Schwartz, S.H.; Bilsky, W. Toward a universal psychological structure of human values. J. Pers. Soc. Psychol. 1987, 53, 550. [CrossRef]

23. Holbrook, M.B. Customer value- A framewrok for analysis and research. In NA-Advances in Consumer Research; Association for Consumer Research: Provo, UT, USA, 1996; Volume 23, pp. 138-143.

24. Long, M.M.; Schiffman, L.G. Consumption values and relationships: Segmenting the market for frequency programs. J. Consum. Mark. 2000, 17, 214-232. [CrossRef]

25. Kilbourne, W.; Pickett, G. How materialism affects environmental beliefs, concern and environmentally responsible behavior. J. Bus. Res. 2008, 61, 885-893. [CrossRef]

26. Leroi-Werelds, S.; Streukens, S.; Brady, M.K.; Swinnen, G. Assessing the value of commonly used methods for measuring customer value: A multi-setting empirical study. J. Acad. Mark. Sci. 2014, 42, 430-451. [CrossRef]

27. Han, L.; Wang, S.; Zhao, D.; Li, J. The intention to adopt electric vehicles: Driven by functional and non-functional values. Transp. Res. Part A Policy Pract. 2017, 103, 185-197. [CrossRef] 
28. Jamrozy, U.; Lawonk, K. The multiple dimensions of consumption values in ecotourism. Int. J. Cult. Tour. Hosp. Res. 2017, 11, 18-34. [CrossRef]

29. Lin, P.-C.; Huang, Y.-H. The influence factors on choice behavior regarding green products based on the theory of consumption values. J. Clean. Prod. 2012, 22, 11-18. [CrossRef]

30. Bei, L.-T.; Simpson, E.M. The determinants of consumers' purchase decisions for recycled products: An application of acquisition-transaction utility theory. In NA-Advances in Consumer Research; Association for Consumer Research: Provo, UT, USA, 1995; Volume 22, pp. 257-261.

31. Finch, J.E. The impact of personal consumption values and beliefs on organic food purchase behavior. J. Food Prod. Mark. 2006, 11, 63-76. [CrossRef]

32. Biswas, A.; Roy, M. Green products: An exploratory study on the consumer behaviour in emerging economies of the East. J. Clean. Prod. 2015, 87, 463-468. [CrossRef]

33. Wang, S.; Wang, J.; Wang, Y.; Yan, J.; Li, J. Environmental knowledge and consumers' intentions to visit green hotels: The mediating role of consumption values. J. Travel Tour. Mark. 2018, 35, 1261-1271. [CrossRef]

34. Van Birgelen, M.; Semeijn, J.; Keicher, M. Packaging and proenvironmental consumption behavior: Investigating purchase and disposal decisions for beverages. Environ. Behav. 2009, 41, 125-146. [CrossRef]

35. Tsay, Y.-Y. The impacts of economic crisis on green consumption in Taiwan. In Proceedings of the 2009 Portland International Conference on Management of Engineering \& Technology, Portland, OR, USA, 2-6 August 2009; pp. 2367-2374.

36. Malhotra, G.; Maheshwari, A. Green marketing: A study on Indian youth. Int. J. Manag. Strateg. 2011, 2, $1-15$.

37. Wan, W.; Birch, J.B. A semiparametric technique for the multi-response optimization problem. Qual. Reliab. Eng. Int. 2011, 27, 47-59. [CrossRef]

38. Laroche, M.; Bergeron, J.; Barbaro-Forleo, G. Targeting consumers who are willing to pay more for environmentally friendly products. J. Consum. Mark. 2001, 18, 503-520. [CrossRef]

39. Eriksson, C. Can green consumerism replace environmental regulation?-A differentiated-products example. Resour. Energy Econ. 2004, 26, 281-293. [CrossRef]

40. Lung, S. Green Consumerism-The way to effectively differentiate your products in Asia-Pacific Market. Online Artic. 2010. Available online: http://ezinearticles.com/?Green-Consumerism---The-Way-to-EffectivelyDifferentiate-Your-Products-in-Asia-Pacific-Market\&id=4875312 (accessed on 22 December 2018).

41. Rahnama, H.; Rajabpour, S. Identifying effective factors on consumers' choice behavior toward green products: The case of Tehran, the capital of Iran. Environ. Sci. Pollut. Res. 2017, 24, 911-925. [CrossRef] [PubMed]

42. Sweeney, J.C.; Soutar, G.N. Consumer perceived value: The development of a multiple item scale. J. Retail. 2001, 77, 203-220. [CrossRef]

43. Oliver, J.D.; Lee, S.-H. Hybrid car purchase intentions: A cross-cultural analysis. J. Consum. Mark. 2010, 27, 96-103. [CrossRef]

44. Sangroya, D.; Nayak, J.K. Will Indian Industrial Energy Consumer Continue to Buy Green Energy? Organ. Environ. 2017, 30, 253-274. [CrossRef]

45. Cohen, J.; Pham, M.; Andrade, E. The nature and role of affect in consumer behavior. In Handbook of Consumer Psychology; Haugtvedt, C.P., Herr, P.M., Kardes, F.R., Eds.; Taylor \& Francis Group/Lawrence Erlbaum Associates: New York, NY, USA, 2008; pp. 297-348.

46. Erevelles, S. The role of affect in marketing. J. Bus. Res. 1998, 42, 199-215. [CrossRef]

47. Loewenstein, G.; Lerner, J.S. The role of affect in decision making. Handb. Affect. Sci. 2003, 619, 3.

48. Mellers, B.; Schwartz, A.; Ritov, I. Emotion-based choice. J. Exp. Psychol. Gen. 1999, 128, 332. [CrossRef]

49. Belk, R.W. An exploratory assessment of situational effects in buyer behavior. J. Mark. Res. 1974, 11, $156-163$. [CrossRef]

50. Laaksonen, M. Retail patronage dynamics: Learning about daily shopping behavior in contexts of changing retail structures. J. Bus. Res. 1993, 28, 3-174. [CrossRef]

51. Lai, A.W. Consumption situation and product knowledge in the adoption of a new product. Eur. J. Mark. 1991, 25, 55-67.

52. Hirschman, E.C. Innovativeness, novelty seeking and consumer creativity. J. Consum. Res. 1980, 7, $283-295$. [CrossRef] 
53. Ginsberg, J.M.; Bloom, P.N. Choosing the right green marketing strategy. MIT Sloan Manag. Rev. 2004, 46, $79-84$.

54. Suki, N.M. Consumer environmental concern and green product purchase in Malaysia: Structural effects of consumption values. J. Clean. Prod. 2016, 132, 204-214. [CrossRef]

55. Arvola, A.; Vassallo, M.; Dean, M.; Lampila, P.; Saba, A.; Lähteenmäki, L.; Shepherd, R. Predicting intentions to purchase organic food: The role of affective and moral attitudes in the Theory of Planned Behaviour. Appetite 2008, 50, 443-454. [CrossRef]

56. Dholakia, U.M. A motivational process model of product involvement and consumer risk perception. Eur. J. Mark. 2001, 35, 1340-1362. [CrossRef]

57. Khan, M.N.; Kirmani, M.D. Influence of environmental characteristics of the consumers on their willingness to pay for green products: An empirical investigation. Int. J. Soc. Entrep. Innov. 2015, 3, 374-386. [CrossRef]

58. Iranmanesh, M.; Jayaraman, K.; Zailani, S.; Ghadiri, S.M. The effects of consumer perception of volume discount benefits on intention to purchase grocery products: Deal proneness as a moderator. Asia Pac. J. Mark. Logist. 2017, 29, 1017-1035. [CrossRef]

59. Faul, F.; Erdfelder, E.; Buchner, A.; Lang, A.-G. Statistical power analyses using G* Power 3.1: Tests for correlation and regression analyses. Behav. Res. Methods 2009, 41, 1149-1160. [CrossRef]

60. Hair, J.F.; Ringle, C.M.; Sarstedt, M. PLS-SEM: Indeed a silver bullet. J. Mark. Theory Pract. 2011, 19, $139-152$. [CrossRef]

61. Hair, J.F., Jr.; Hult, G.T.M.; Ringle, C.; Sarstedt, M. A Primer on Partial Least Squares Structural Equation Modeling (PLS-SEM); SAGE Publications, Inc.: Thousand Oaks, CA, USA, 2013; ISBN 1483321452.

62. Yusof, N.; Rahman, S.; Iranmanesh, M. The environmental practice of resorts and tourist loyalty: The role of environmental knowledge, concern and behaviour. Anatolia 2016, 27, 214-226. [CrossRef]

63. Zainuddin, Z.B.; Zailani, S.; Govindan, K.; Iranmanesh, M.; Amran, A. Determinants and outcome of a clean development mechanism in Malaysia. J. Clean. Prod. 2017, 142, 1979-1986. [CrossRef]

64. Weng, G.S.; Zailani, S.; Iranmanesh, M.; Hyun, S.S. Mobile taxi booking application service's continuance usage intention by users. Transp. Res. Part D Transp. Environ. 2017, 57, 207-216. [CrossRef]

65. Nikbin, D.; Iranmanesh, M.; Hyun, S.S.; Baharun, R.; Kim, I. The role of airline travelers' pre-recovery emotions during the service recovery process. J. Travel Tour. Mark. 2015, 32, 677-691. [CrossRef]

66. Zailani, S.; Iranmanesh, M.; Masron, T.A.; Chan, T.-H. Is the intention to use public transport for different travel purposes determined by different factors? Transp. Res. Part D Transp. Environ. 2016, 49, 18-24. [CrossRef]

67. Awang, H.; Iranmanesh, M. Determinants and outcomes of environmental practices in Malaysian construction projects. J. Clean. Prod. 2017, 156, 345-354.

68. Hair, J.F.; Wolfinbarger, M.F.; Ortinau, D.J.; Bush, R.P. Essentials of Marketing Research; McGraw-Hill/Irwin: New York, NY, USA, 2010; ISBN 0073404829.

69. Fornell, C.; Larcker, D.F. Evaluating structural equation models with unobservable variables and measurement error. J. Mark. Res. 1981, 18, 39-50. [CrossRef]

70. Chin, W.W. How to write up and report PLS analyses. In Handbook of Partial Least Squares: Concepts, Methods and Application; Vinzi, V.E., Chin, W.W., Eds.; Springer: Berlin/Heidelberg, Germany, 2010; pp. 655-690. ISBN 3540328254.

71. Wetzels, M.; Odekerken-Schroder, G.; Van Oppen, C. Using PLS path modeling for assessing hierarchical construct models: Guidelines and empirical illustration. Mis Q. 2009, 33, 177-195. [CrossRef]

72. Singh, G.; Pandey, N. The determinants of green packaging that influence buyers' willingness to pay a price premium. Australas. Mark. J. 2018, 26, 221-230. [CrossRef]

73. Kalafatis, S.P.; Pollard, M.; East, R.; Tsogas, M.H. Green marketing and Ajzen's theory of planned behaviour: A cross-market examination. J. Consum. Mark. 1999, 16, 441-460. [CrossRef]

(C) 2019 by the authors. Licensee MDPI, Basel, Switzerland. This article is an open access article distributed under the terms and conditions of the Creative Commons Attribution (CC BY) license (http:/ / creativecommons.org/licenses/by/4.0/). 